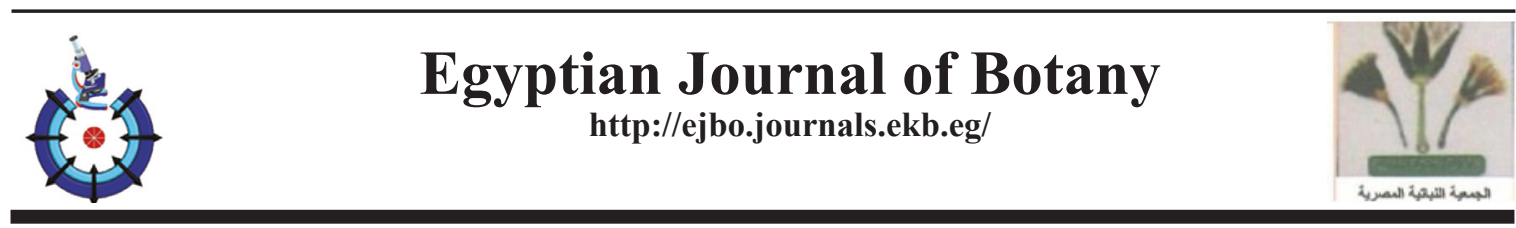

\title{
Characterization and Antibacterial Effects of Microcystis aeruginosa Extracts
}

\author{
Mohamed A.I. Deyab, Ahmed K.A. EL-Sayed and Seham E.A. Abu-Ahmed \\ Botany and Microbiology Department, Faculty of Science, Damietta University, \\ Damietta El-Gededa, P.O. 34517, Egypt.
}

\begin{abstract}
$\boldsymbol{M}$ ICROCYSTIS aeruginosa MDEG1 strain from El-Manzala Lake (Damietta, Egypt) was identified classically by its morphological characteristics. Its identification was confirmed using 16S rRNA gene sequencing. Different concentrations (1, 10, 25 and 50mg/ $\mathrm{ml}$ ) of petroleum ether and chloroform of $M$. aeruginosa MDEG1 extracts were examined for their antibacterial activity by well diffusion technique. Petroleum ether extract had a high activity against $K$. pneumoniae, P. aeruginosa and $S$. aureus. Chloroform extract exhibited higher activity against $K$. pneumoniae. Gas chromatography, mass spectrophotometry (GCMS) and H-proton nuclear magnetic resonance ( $\left.{ }^{1} \mathrm{H}-\mathrm{NMR}\right)$ analysis revealed the presence of Hexadecanoic acid (Palmitic acid) and its methyl ester derivative as major constituents of petroleum ether and chloroform algal extract, that might be involved in their antibacterial activity. The cytomorphology using scanning electron microscopy (SEM) for treated $K$. pneumonia (Nosocomial infection bacteria) with M. aeruginosa extract (Chloroform, 50mg/ $\mathrm{ml}$ ) showed appearance of giant cell formation, while transmission electron microscope (TEM) showed ruptured bacterial cell wall damage with extrusion of cytoplasmic content indicating its bactericidal effect.
\end{abstract}

Keywords: Cyanobacteria, M. aeruginosa, Antimicrobial activity, SEM, TEM.

\section{Introduction}

The cyanobacteria have been recognized to provide chemical and pharmacological novelty and diversity. They are a rich source of bio-fertilizers, food, feed, antimicrobial agents and they produce compounds that have potential biotechnological application (Muruga et al., 2014). They provide a safer and cost effective way of treating bacterial infections (Pradhan et al., 2014). Cyanobacteria are especially abundant in shallow, warm, nutrient rich or polluted water low in oxygen and can grow to form thick scums that could color the water, creating blooms (Stotts et al., 1993). M. aeruginosa is one of the most widespread and bloom-forming species in the fresh and brackish water (Rzymski et al., 2014). Microcystis (order Chrococcales and class Cyanophyceae) occurs in the form of characteristic colonies that can be classified as different morphological types (morphotypes), each of which is equivalent to a species (morphospecies) (Komárek \& Anagnostidis, 1999). Microcystis colonies differ in shape and size, but also in the appearance of their mucilage (Via-Ordorika et al., 2004). Molecular identification of Microcystis had been established by using 16S rRNA gene sequencing to differentiate between its species (Neilan et al., 1997; Otsuka et al., 1998).

Although, antibiotics have been widely used in last decades, the development of microbial resistance to them is also increased (Mohamed et al., 2018a). In order to overcome this problem, the exploring of new antibacterial substances from bioactive algal compounds especially from cyanobacteria is as an alternative solution and an important necessity (Tajbakhsh et al., 2011). This is due to their wide biological activities, low cost and higher safety compared to synthetic

"Corresponding author email: snowwhite201443@yahoo.com

Received 21/6/2017; Accepted 21/4/2019

DOI: 10.21608/ejbo.2019.1249.1109

Edited by: Prof. Dr. Mostafa M. Elsheekh, Faculty of Science, Tanta University, Tanta, Egypt.

(C)2019 National Information and Documentation Center (NIDOC) 
drugs (Grabley \& Thiericke, 1999). Fatty acids (FAs) are ubiquitous molecules typically bound to other compounds such as glycerol, sugars or phosphate head groups to form lipids. FAs can be released from lipids, typically by enzyme action, to become free fatty acids (FFAs) which have diverse and potent antibacterial activities (Desbois et al., 2009). The antibacterial activity of each FFA is influenced by its structure and shape. This, in turn, is a function of the carbon chain length and the presence, number, position and/or orientation of the double bonds (Zheng et al., 2005).

Usually, the antimicrobial compounds have a severe effect on the exposed microorganisms' cells. Generally, the morphological abnormalities of the bacterial cells were observed by scanning electron microscopy (Mohamed et al., 2018b). On the other hand, formation of extracellular capsular polysaccharides, changes in cell size, and cell division alterations were also determined by analysis of transmission electron microscopy (Alexander et al., 2006).

The aim of the current work is to determine the biological capacity of Microcystis aeruginosa isolate in relative to its antibacterial activity and its cytomorphological effect on Klebsiella pneumoniae.

\section{Materials and Methods}

\section{Collection of the algal sample}

Algal bloom of Microcystis aeruginosa (order Chrococcales and class Cyanophyceae) has highest cell density (99\%) during late autumn months (November) as recorded at El-Manzala Lake (brackish water). The bloom sample was collected with plankton net of $10 \mu \mathrm{m}$ mesh size. The samples were then spread on string nets allowed to dry in air. Air- dried samples were weighed to evaluate the dry wt., grounded and stored in stoppered bottles in refrigerator.

\section{Genomic DNA extraction}

Chromosomal DNA was extracted by phenol/ chloroform technique according to procedure modified from (Ausubel et al., 1996). $1.5 \mathrm{ml}$ of fresh cell suspension was centrifuged at $6.500 \mathrm{rpm}$ for $5 \mathrm{~min}$. The pellet was suspended in $1 \mathrm{ml}$ Sucrose-EDTA-Tris-HCL (SET buffer) $(20 \%$ sucrose, 50mM Tris-HCl, PH 7.6, 50mM EDTA) for washing by centrifugation at $6.500 \mathrm{rpm}$ for another $5 \mathrm{~min}$. The pellet was re-suspended in $100 \mu 1$ SL buffer (SET buffer + Lysozyme), vortex and followed by the addition of $2 \mu$ R Rase. After incubation at $37^{\circ} \mathrm{C}$ for $10 \mathrm{~min}, 500 \mu \mathrm{TE}$ buffer (10mM Tris $\mathrm{HCl}, \mathrm{pH} 7.6,0.2 \mathrm{mM}$ EDTA) and $50 \mu \mathrm{l}$ of $10 \%$ sodium dodecyl sulfate were added. DNA was extracted with $500 \mu \mathrm{l}$ of phenol/ chloroform isoamyl alcohol solution (25:24:1), centrifuged at $6.500 \mathrm{rpm}$ for $5 \mathrm{~min}$ and precipitated with cold isopropanol. DNA was harvested by centrifugation at $6.500 \mathrm{rpm}$ for $10 \mathrm{~min}$, washed with $500 \mu$ of $75 \%$ cold ethanol and the DNA pellet was suspended in 1/10 TE buffer and stored at $-20^{\circ} \mathrm{C}$ until used for PCR amplification.

\section{Primers and PCR conditions}

The 16S rRNA gene was amplified by using a pair of universal primers (Neilan et al. (1997), specific for prokaryotes (27 F: AGAGTTTGATCCTGGCTCAG and 1494 R: TACGGCTACCTTGTTACGAC). The PCR product was sequenced by an automated sequencer (Macrogen, South Korea) using the same previous primers.

\section{Agarose gel electrophoresis}

The detection of genomic DNA and size of PCR products were examined by agarose gel electrophoresis. $1 \%$ agarose was dissolved in TAE buffer pH8.0 (0.04M Tris-acetate, $0.001 \mathrm{M}$ EDTA). For DNA visualization, $2 \mu$ l ethidium bromide $(10 \mathrm{mg} / \mathrm{ml})$ were added and the gel was examined by UV transilluminator. Usually $2 \mu \mathrm{l}$ of loading buffer $(0.25 \%$ Bromophenol blue, $70 \%$ Glycerol, $10 \mathrm{mM}$ Tris- $\mathrm{HCl} \mathrm{pH}$ 7.0), $1 \mathrm{~Kb}$ DNA Ladder (Fermentans) were used as molecular marker to indicate the size of the DNA fragments.

\section{Alignment and phylogenetic analysis}

BLAST (Altschul et al., 1997) was performed for the resulting 16S rDNA sequence to match the best similarities with other related sequences on database. The best DNA sequence similarities obtained from NCBI GenBank were aligned with our 16S rDNA sequence using CLUSTAL Omega. Unalignable regions were excluded manually and the sequences from the same species and unidentified organisms were discarded. MEGA version 4 was used for phylogenetic tree analysis and viewing. The neighbor-joining was performed using the maximum composite likelihood methods with confidence levels estimated by 1000 bootstrap replicates (Tamura et al., 2007). 


\section{Algal extraction}

About $200 \mathrm{~g}$ of air dried $M$. aeruginosa were soaked in methanol and left overnight at room temperature, then filtered off. The marc was washed several times with methanol then the filtrate was evaporated under reduced pressure to afford the crude extract, and then stored in dark containers at $4^{\circ} \mathrm{C}$ until usage (Perumal et al., 2012). Successive extraction to exhaustion was done with petroleum ether $\left(60-80^{\circ} \mathrm{C}\right)$ followed by chloroform. The marc after each extraction was dried until freed from the solvent, before extraction with the next solvent. The obtained extracts were separately concentrated under reduced pressure, dried to constant weight in vacuum desiccators, weighed and reserved in the refrigerator until further investigation.

\section{GC-MS analysis}

The compounds identification was performed by an Agilent 6890 Gas Chromatograph (GC) equipped with an Agilent Mass Spectrometric (MS) detector, with capillary interface and fused silica capillary column PAS $5 \mathrm{~ms}(30 \mathrm{~m}$ $\times 0.32 \mathrm{~mm} \times 0.25 \mathrm{~mm}$ film thickness) at Cairo Agricultural Research Center. $1 \mathrm{ml}$ of algal extract sample was injected under helium as a carrier gas at approximately $1 \mathrm{ml} / \mathrm{min}$, pulsed split less mode and solvent delay was $3 \mathrm{~min}$. The mass spectrophotometric detector was operated in electron impact ionization mode with energy of 70e.v. scanning from $\mathrm{m} / \mathrm{z} 50$ to 500. The instrument was manually tuned using perfluorotributy 1 amine (PFTBA).

\section{${ }^{1} \mathrm{H}$ NMR spectra analysis}

H-Proton Nuclear Magnetic Resonance ( ${ }^{1} \mathrm{H}-\mathrm{NMR}$ ) spectra were obtained using $300 \mathrm{MHz}$ Bruker NMR instrument. Chemical shifts are given in $\delta(\mathrm{ppm})$ relative to TMS as internal standard material at Faculty of Science, Kafr ElSheikh University.

\section{Antibacterial assay}

The total extracts of petroleum ether and chloroform were decolorized on activated charcoal and then filtered. Each filtrate was taken to dryness under reduced pressure at $40^{\circ} \mathrm{C}$. Part of the obtained thick tarry residues was dissolved in dimethyl sulfoxide (DMSO) to make 1, 10, 25 and $50 \mathrm{mg} / \mathrm{ml}$ concentrations, and then screened for the presence of antibacterial activities against bacteria (Staphylococcus aureus, Bacillus cereus, Bacillus subtilis, Escherichia coli, Pseudomonas aeruginosae, Klebsiella pneumoniae and Proteus marbilis), which were kindly provided from the Laboratory of Bacteriology, Faculty of Science, Damietta University, Egypt.

Pore plate method was performed on medium contains $5 \mathrm{~g}$ glucose, $5 \mathrm{~g}$ peptone, $5 \mathrm{~g}$ sodium chloride, $3 \mathrm{~g}$ beef extract and $15 \mathrm{~g}$ agar, dissolved in distilled water up to 1L (Hornsey \& Hide, 1974). $0.3 \mathrm{ml}$ of algal extract was introduced into $10 \mathrm{~mm}$ well diameter. For the control, $0.3 \mathrm{ml}$ of DMSO was used. Inhibition zones were read one day after incubation at $37^{\circ} \mathrm{C}$. Each assay was repeated three times and the mean values were recorded.

\section{Scanning electron microscopy}

Agar cultures with bacterial colonies were first excised and trimmed to approximately $10 \mathrm{~mm}$ $\mathrm{x} 10 \mathrm{~mm}$ specimens as thin as possible $(1-2 \mathrm{~mm})$, and fixed in a buffered $(0.1 \mathrm{M}$ phosphate buffer, $\mathrm{pH}$ 6.5-7.0) fixative 2-3\% glutaraldehyde for periods ranging from $5 \mathrm{~min}$ to $24 \mathrm{hr}$ before they were further reduced into smaller (about $5 \mathrm{~mm} \mathrm{x}$ 5mm) specimens (Glauert, 1975; Erdos, 1986). Then, the specimens were post-fixed in $1 \%$ osmium tetroxide in the same buffer, dehydrated in a graded series of acetone. Critical-point dried specimens were coated with gold palladium in a polaron E500 sputter coater (Polaron Equipment Ltd., England) and viewed in Scanning Electron Microscope (JEOL JSM 35C) at the EM unit, Faculty of Science, Alexandria University.

\section{Transmission electron microscopy}

The tested bacteria were inoculated in nutrient broth media containing algal extract at final concentration $(50 \mathrm{mg} / \mathrm{ml})$. Also, control untreated bacteria were included. After incubation time, the bacteria were centrifuged, and then fixed with formalin-glutaraldehyde fixative $\left({ }_{4} \mathrm{~F}_{1} \mathrm{G}\right)$ in $0.1 \mathrm{M}$ phosphate buffer $\mathrm{pH}$ 7.4. After rinsing in the buffer, samples were post-fixed in $2 \%$ osmium tetroxide for $2 \mathrm{hr}$ at $4^{\circ} \mathrm{C}$ in the same buffer. The cells were washed and dehydrated at $4^{\circ} \mathrm{C}$ through a graded series of ethanol. Cells were then treated with propylene oxide solution and embedded in a mixture of $1: 1$ of Epon-Araldite for $1 \mathrm{hr}$. Polymerization was done in the oven at $65^{\circ} \mathrm{C}$ for $24 \mathrm{hr}$. Ultrathin sections $(50 \mu \mathrm{m})$ were cut on ultratome (Model LKB), then mounted on copper grids, double stained with uranyl acetate and lead citrate and investigated on a JEOL 100CX TEM at the EM unit, Faculty of Science, Alexandria University. 


\section{Results}

Morphological characteristics of Microcystis

The colony morphology, size and mucilage characteristics of the Microcystis isolate were performed. The colonies were more or less spherical, and the cells usually 4-6 $\mu \mathrm{m}$ in diameter, sparsely to densely agglomerated and contained gas vesicles. The mucilage was colorless, structureless and did not form a very wide margin around the cells. According to Komárek \& Anagnostidis (1999), this morphospecies can assign to Microcystis aeruginosa MDEG1 isolate.

\section{Molecular identification of Microcystis}

The 16S rRNA gene sequencing of the PCR product for the Microcystis isolate MDEG1 resulted 1428bp (Accession No. MG979399). Its DNA sequence alignment revealed high similarity with some different species of Microcystis including $M$. aeruginosa. The best identity reached $100 \%$ with M. aeruginosa (Accession No. D89031). The other species were closely clustered as one group with less identity with the studied $M$. aeruginosa isolate, while $M$. elabens (AB001724) and M. holsatica (Accession No. D89036) were clustered away in separate clade (Fig. 1).

\section{Bioactivity of $M$. aeruginosa extract}

The antibacterial activity of $M$. aeruginosa MDEG1 strain against $S$. aureus, B. cereus, $B$. subtilis, E. coli, $P$. aeruginosa, $K$. pneumoniae and $P$. marbilis was evaluated. Generally, $50 \mathrm{mg} /$ $\mathrm{ml}$ algal extract concentration showed the highest effect against all bacterial species (Table 1). Petroleum ether extract of M. aeruginosa MDEG1 possessed a good activity against most of the Gram negative bacteria (K. pneumoniae and P. aeruginosa) and also Gram positive bacteria (S. aureus). On the other hand, the chloroform extract exhibited higher activity against Gram negative bacteria (K. pneumoniae) and showed lower activity against the other tested bacteria. Furthermore, all concentrations of both extracts showed no activity against Bacillus subtilis.

\section{Compounds identification}

The petroleum ether extract of Microcystis aeruginosa contained 19 compounds. They comprised 18 aliphatic compounds (10 fatty acids, 4 alkanes, 2 monoterpenoids, 1 fatty alcohol and 1 hexadecanoic acid), and only one was aromatic. The major constituent with a peak area $48.43 \%$ and retention time $\left(\mathrm{R}_{t}\right) 21.71$ was for hexadecanoic acid (palmitic acid). The compound 2, 2-dimethyl7-methoxy-2, 3-dihydro-2H-benzo[b]thiene gave the peak area $0.13 \%$ and retention time $\left(\mathrm{R}_{\mathrm{t}}\right) 15.41$ (Table 2). The algal chloroform extract revealed 16 compounds mainly aliphatic fatty acids and fatty acid methyl ester, only three of them were heterocyclic compounds ( $\beta$-pinene. loliolide, and 2-hydroxy-5,6-epoxy- $\beta$-ionone). The main constituent was palmitic acid, methyl ester with $78.98 \%$ peak area and $\mathrm{R}_{\mathrm{t}}$ at 39.81 .

\section{Cytomorphological effect of $M$. aeruginosa extracts}

The most sensitive strain (K. pneumoniae, Nosocomial infection bacteria) was chosen to study the effect of $50 \mathrm{mg} / \mathrm{ml} \mathrm{M}$. aeruginosa chloroform extract on its cytomorphology and ultrastructure using scanning electron microscopy (SEM) and transmission electron microscopy (TEM). The SEM revealed that the exposure of $K$. pneumoniae cells to chloroform extract of $M$. aeruginosa resulted in giant cell formation and appearance of elongated filament like structure, compared with normal straight rod cells arranged singly or in pairs for the untreated bacteria (Fig. 2). The TEM micrographs of treated $K$. pneumoniae revealed successive bactericidal effects including electron dense granules and electron lucent vacuoles formation in the cytoplasm, weakening and damaging of the boundary cell wall, cell malformation, loose attachment of cell membrane, twisted cell were clearly visible and finally granular cell contents exudes from the damaged membrane. The untreated cells exhibited normal appearance with polysaccharide capsule of considerable thickness which was closely adhering to the cell wall (Fig. 3).

\section{Discussion}

Microcystis is a coccoid cell shape with tendency to form aggregates of colonies having gas vesicles and amorphous mucilage or a sheath (Komárek \& Anagnostidis, 1999). Based on the previous criteria, ten species of Microcystis had been characterized in Europe including $M$. aeruginosa (Kützing) Kützing, M. botrys (Teiling), M. firma (Kützing) Schmidle, M. flosaquae (Wittrock) Kirchner, M. ichthyoblabe (Kützing), M. natans (Lemmermann) ex Skuja, M. novacekii (Komárek) Compère, M. smithii (Kützing and Anagnostidis), M. viridis (A. Braun in Rabenhorst) Lemmermann and $M$. wesenbergii 
(Komárek) Komárek in Kondratieva. Many other species had been also identified outside Europe. The morphospecies $M$. aeruginosa have been identified in brackish water blooming from El-
Manzala Lake, Damietta, Egypt. Some species including $M$. aeruginosa are often found in North African freshwater habitats (Nasri et al., 2004) and drinking water sources (Chiu et al., 2017).

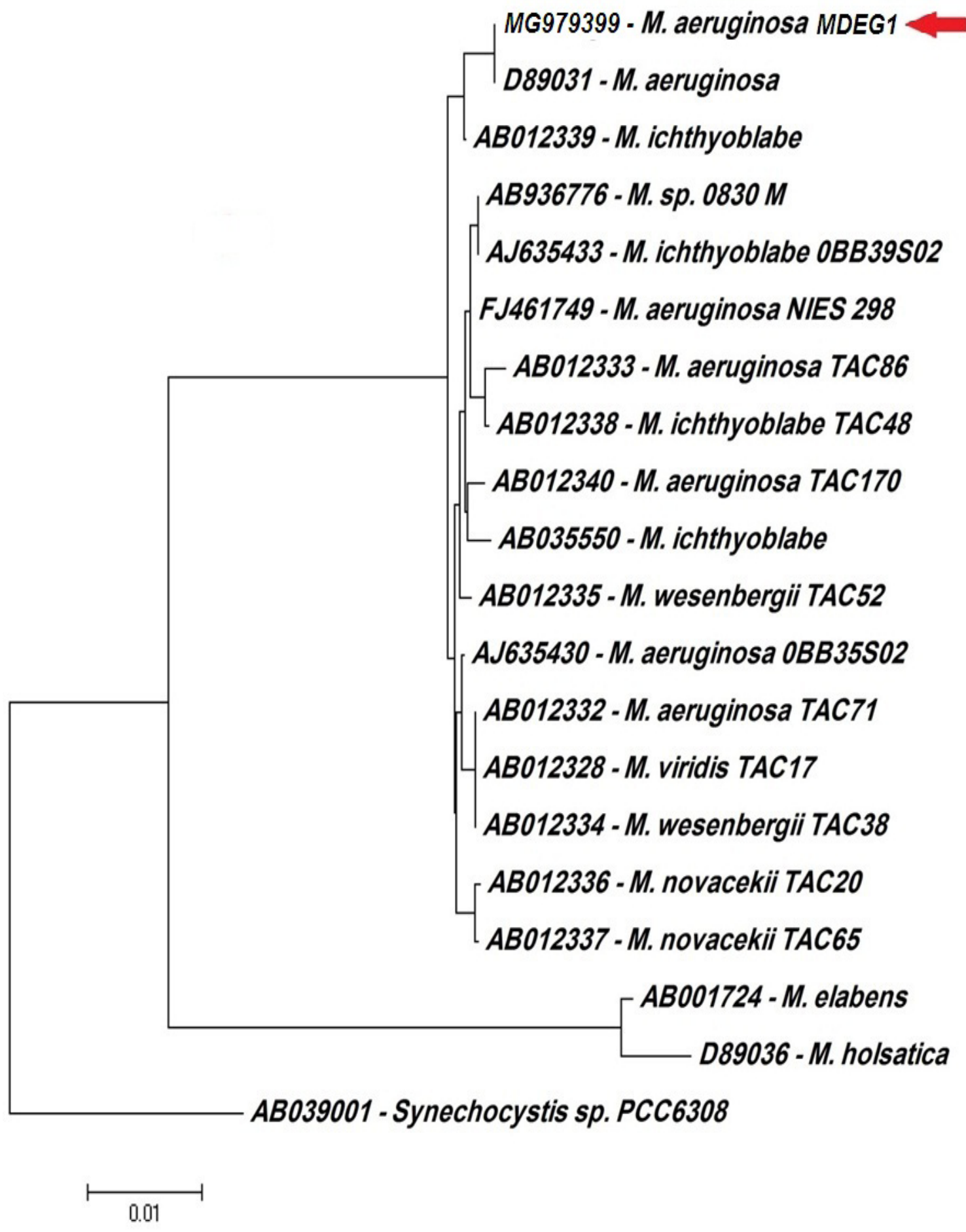

Fig. 1. Phylogenetic tree based on the 16S rDNA sequence for M. aeruginosa MDEG1 (AC: MG 979399) with other related members of Microcystis [The rooting of the tree was achieved by Synechocystis sp, PCC6308 (AC: AB0 39001)]. 
TABLE 1. Antibacterial activity (as inhibition zone diameter mm) of different extracts of Microcystis aeruginosa MDEG1.

\begin{tabular}{lcccccccc}
\hline & \multicolumn{3}{c}{$\begin{array}{c}\text { Petroleum ether extract } \\
\text { Tested bacteria }\end{array}$} & \multicolumn{1}{c}{ ( $\mathbf{m l}$ in DMSO } & & \multicolumn{3}{c}{$\begin{array}{c}\text { Chloroform extract } \\
(\mathbf{m g} / \mathbf{m l}) \text { in DMSO }\end{array}$} \\
\cline { 2 - 9 } & $\mathbf{1}$ & $\mathbf{1 0}$ & $\mathbf{2 5}$ & $\mathbf{5 0}$ & $\mathbf{1}$ & $\mathbf{1 0}$ & $\mathbf{2 5}$ & $\mathbf{5 0}$ \\
\hline S. aureus & $3 \pm 0.6$ & $7 \pm .6$ & $10 \pm 0.3$ & $13 \pm 0.6$ & $1 \pm 0.3$ & $2 \pm 0.3$ & $3 \pm 0.9$ & $5 \pm 0.9$ \\
B. cereus & $1 \pm 0.3$ & $5 \pm 0.6$ & $6 \pm 0.6$ & $7 \pm 0.6$ & $2 \pm 0.6$ & $2 \pm 0.6$ & $3 \pm 0.6$ & $5 \pm 0.6$ \\
B. subtilis & $\mathrm{Nil}$ & $\mathrm{Nil}$ & $\mathrm{Nil}$ & $\mathrm{Nil}$ & $\mathrm{Nil}$ & $\mathrm{Nil}$ & $\mathrm{Nil}$ & $\mathrm{Nil}$ \\
E. coli & $2 \pm 0.6$ & $3 \pm 0.6$ & $4 \pm 0.3$ & $5 \pm 0.6$ & $1 \pm 0.3$ & $1 \pm 0.3$ & $1 \pm 0.3$ & $2 \pm 0.6$ \\
P. aeroginosa & $6 \pm 0.3$ & $7 \pm 0.6$ & $9 \pm 0.6$ & $12 \pm 0.3$ & $1 \pm 0$ & $2 \pm 0.6$ & $2 \pm 0.6$ & $2 \pm 0.6$ \\
K. pneumoniae & $5 \pm 0.6$ & $12 \pm 0.6$ & $15 \pm 0.6$ & $16 \pm 0.6$ & $10 \pm 0.6$ & $12 \pm 0.6$ & $15 \pm 0.6$ & $16 \pm 0.3$ \\
P. marbilis & $\mathrm{Nil}$ & $1 \pm 0$ & $3 \pm 0.6$ & $5 \pm 0.6$ & $1 \pm 0.3$ & $2 \pm 0.6$ & $2 \pm 0.6$ & $2 \pm 0.6$ \\
\hline
\end{tabular}

TABLE 2. Identified compounds based on GC-MS and ${ }^{1} \mathrm{H}-\mathrm{NMR}$ analysis for petroleum ether and chloroform extracts of Microcystis aeruginosa MDEG1.

\begin{tabular}{|c|c|c|c|c|c|}
\hline \multicolumn{3}{|l|}{ Petroleum ether } & \multicolumn{3}{|c|}{ Chloroform } \\
\hline Compound name & $\mathbf{R}_{\mathrm{t}}$ & Area \% & Compound name & $\mathbf{R}_{\mathrm{t}}$ & Area \% \\
\hline Nonanoic acid & 10.46 & 0.08 & $\beta$-Pinene & 10.40 & 0.97 \\
\hline Hexanedioic acid mono methyl ester & 11.22 & 0.04 & Loliolide & 34.06 & 0.74 \\
\hline Iso-octadecanoic acid & 11.81 & 0.08 & $\begin{array}{l}\text { Tetradecanoic acid, methyl } \\
\text { ester }\end{array}$ & 34.81 & 0.35 \\
\hline Nonanoic acid, methyl ester & 12.94 & 0.06 & $\begin{array}{l}\text { Tetradecanoic acid, 12-methyl-, } \\
\text { methyl ester }\end{array}$ & 36.40 & 0.54 \\
\hline Oleyl alcohol & 13.55 & 0.14 & 2-hydroxy-5,6-epoxy- $\beta$-ionone & 36.57 & 0.24 \\
\hline Dodecanoic acid & 15.09 & 0.13 & Octadecane & 36.60 & 0.28 \\
\hline $\begin{array}{l}\text { 2,2-dimethyl-7-methoxy-2,3- } \\
\text { dihydro-2H-benzo[b]thiene }\end{array}$ & 15.41 & 0.13 & $\begin{array}{l}\text { 2-pentadecanone, } \\
\text { 6,10,14-trimethyl }\end{array}$ & 37.80 & 5.08 \\
\hline 3-oxo-ß-ionone & 16.66 & 0.25 & Heptadecanoic acid & 39.09 & 0.24 \\
\hline n-heptadecane & 16.94 & 3.25 & $\begin{array}{l}\text { Hexadecanoic acid (Palmitic } \\
\text { acid) }\end{array}$ & 39.80 & 5.54 \\
\hline Tetradecanoic acid, methyl ester & 17.20 & 0.40 & Palmitic acid, methyl ester & 39.81 & 78.98 \\
\hline 2-methyl-heptadecane & 17.68 & 0.25 & Palmitic acid, ethyl ester & 41.48 & 0.71 \\
\hline Octadecane & 18.25 & 2.82 & Oleic acid & 41.90 & 2.17 \\
\hline 2-pentadecanone, 6,10,14-trimethyl & 18.87 & 1.60 & $\begin{array}{l}\text { 3-hydroxytetradecanoic acid } \\
\text { methyl ester }\end{array}$ & 44.07 & 4.85 \\
\hline Nonadecane & 19.49 & 0.53 & Octadecanoic acid, methyl ester & 44.49 & 2.59 \\
\hline Hexadecanoic acid, methyl ester & 20.08 & 13.9 & Octadecanoic acid & 45.97 & 0.31 \\
\hline Hexadecanoic acid (Palmitic acid) & 21.71 & 48.43 & 9-octadecenamide & 46.10 & 1.34 \\
\hline Heptadecanoic acid & 22.11 & 1.04 & & & \\
\hline Iso-octadecanoic acid & 22.82 & 1.02 & & & \\
\hline Octadecanoic acid & 23.08 & 2.26 & & & \\
\hline
\end{tabular}

Egypt. J. Bot. 59, No. 3 (2019) 
A

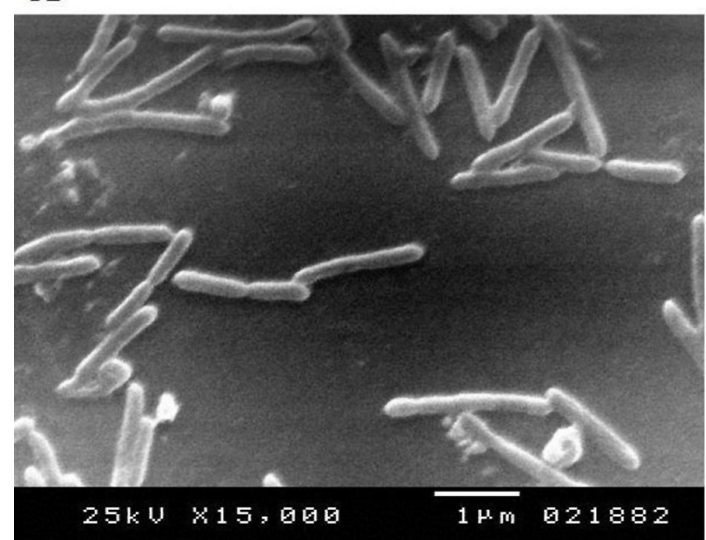

B

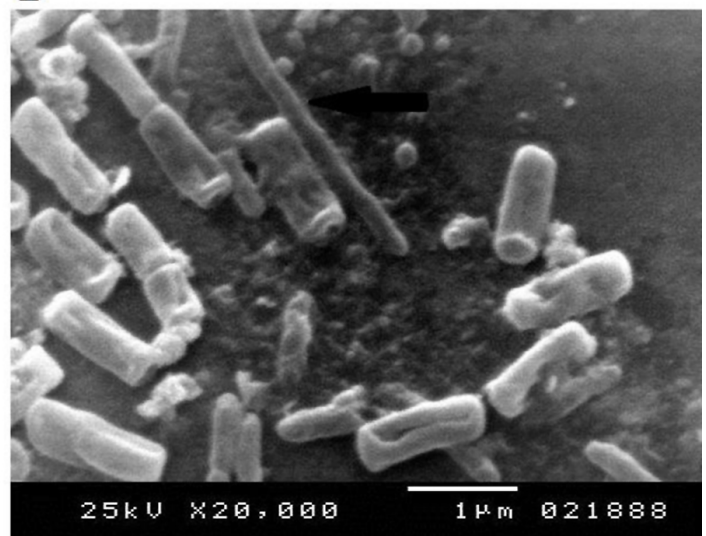

Fig. 2. SEM micrographs of K. pneumoniae; (A) Normal untreated cells with normal cytomorphology (rod cells arranged singly, in pairs or short chains), (B) Bacterial cell elongation with filament-like structure (giant cell) formation due to the effect of chloroform extract of $M$. aeruginosa. Scale bar $=1.0 \mu \mathrm{m}$.

A

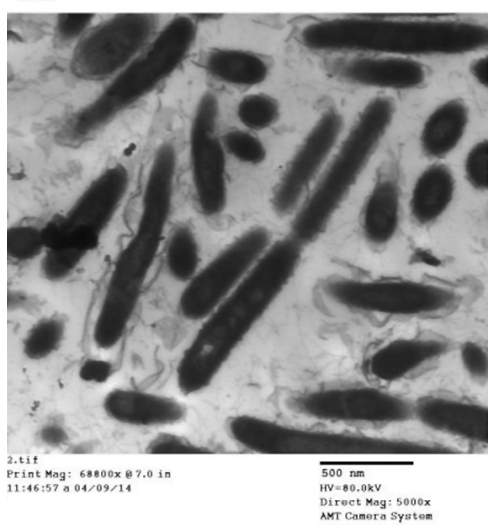

D

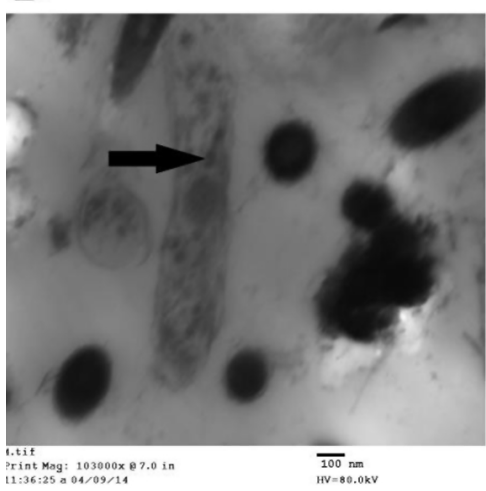

B

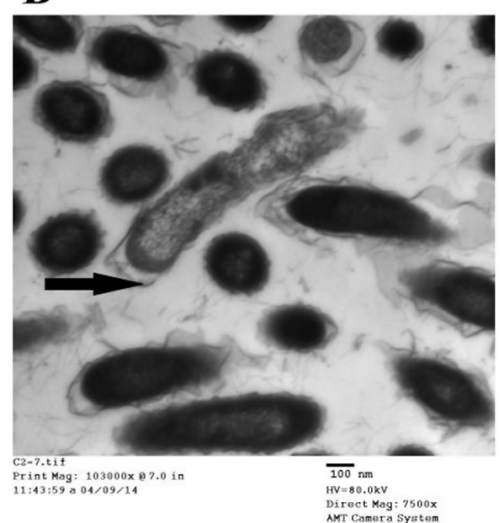

$\mathbf{E}$

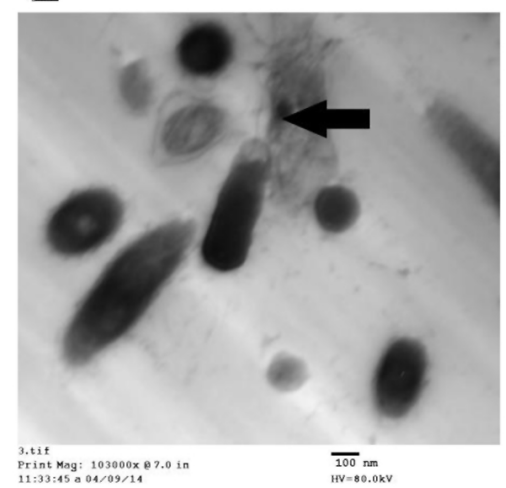

C

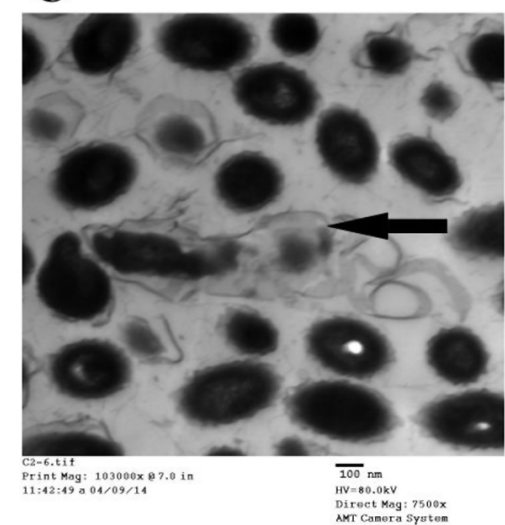

$\mathbf{F}$

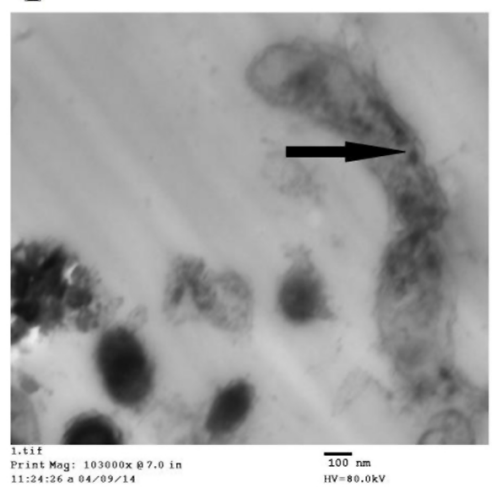

Fig. 3. TEM micrographs of $K$. pneumoniae showed normal cell ultrastructure for untreated bacteria; (A) The treated bacteria with $50 \mathrm{mg} / \mathrm{ml}$ chloroform extract of $M$. aeruginosa revealed abnormalities including loose attachment of cell membrane and cell enlargement (arrow) in B \& $C$; granular cell contents exudes from the damaged membrane (arrow) in D, E \& F [Scale bar $=1.0 \mu \mathrm{m}]$.

The phylogenetic tree based on the $16 \mathrm{~S}$ rDNA analysis confirmed the identification of the $M$. aeruginosa MDEG1 isolate as it exhibited high identity reached $99 \%-100 \%$ in one cluster with some Microcystis species including other M. aeruginosa strains. Several previous studies based on 16S rDNA sequence analysis had shown that different Microcystis species can be clustered 
together (Neilan et al., 1997; Lyra et al., 2001; Rinta-Kanto et al., 2005). Furthermore, Otsuka et al. (1998) found that five Microcystis species: $M$. aeruginosa, $M$. ichthyoblabe, $M$. wesenbergii, $M$. viridis and $M$. novacekii, were so closely related in terms of $16 \mathrm{~S}$ rDNA sequence that they can be grouped as a single species and concluded that the $16 \mathrm{~S}$ rDNA sequence is insufficiently variable to be used for phylogenetic analysis of these organisms at species level. Moreover, Neilan et al. (1997) reported that minor and variable morphometric parameters might have led to the identification of $M$. wesenbergi and $M$. viridis, although it was difficult to justify their separation from $M$. aeruginosa on the basis of the results of $16 \mathrm{~S}$ rRNA gene analysis. The difference in resolution from 16S rRNA in Microcystis matches the reported average sequence diversity of less than 1\% in this gene (Otsuka et al., 1998; Boyer et al., 2001).

Abundant bioactive substances are produced by algae. These substances could have medicinal properties including antibacterial effect. In the present study, we attempted to evaluate the antibacterial activity of $M$. aeruginosa MDEG1 from El-Manzala Lake against $S$. aureus, B. cereus, B. subtilis, E. coli, $P$. aeruginosa, $K$. pneumoniae and $P$. marbilis. The petroleum ether extract of $M$. aeruginosa MDEG1 revealed a considerable high activity against some of the studied Gram negative bacteria (K. pneumoniae and $P$. aeruginosa) and Gram positive bacteria ( $S$. aureus). Meanwhile, chloroform extract exhibited higher activity against $K$. pneumoniae and showed less activity against the other species. Antibacterial substances possessed different solubility according to the solvent used for extraction. The resulting extracts effects may also have differed due to the efficiency of the extraction methods to recover the active metabolites (Tuney, 2006), susceptibility of strains, assay methods and variation in seasonal sampling (Sasidharan et al., 2009). For example, Madhumathi et al. (2011) indicated that ethanol, acetone, diethyl ether and methanol extracts from $M$. aeruginosa and other cyanobacteria possessed different antibacterial activity profiles towards some Gram positive and negative bacteria, and also different antifungal profile activity. The methanolic extract of $M$. aeruginosa showed significant anticyanobacterial activity against Anabaena and Nostoc strains and antialgal activity against a green alga Bracteacoccus with no antibacterial effect (Yadav et al., 2012). An antimicrobial activity was observed also in the hexanic extract of $M$. aeruginosa (RST 9501 strain) against Mycobacterium tuberculosis (Ramos et al., 2015). The highest antifungal activity against all the tested mycotoxigenic fungi was observed when diethyl ether extract of $M$. aeruginosa was applied (Marrez \& Sultan, 2016). The microbiocidal effect of the $M$. aeruginosa MDEG1 extracts might be attributed to the presence of aliphatic fatty acids such as hexadecanoic acid methyl ester which is the major component in chloroform extract, and also hexadecanoic acid which is the major constituent in the petroleum ether extract. Choi \& Jang (2014) stated that some fatty acids like hexanedioic acid have antibacterial activities. It was also reported that dodecanoic acid had bioactivity against Gram positive $S$. aureus and Gram negative $E$. coli bacteria (Kumar et al., 2011). Butylated hydroxytoluene and hexadecanoic acid were also detected in M. aeruginosa that might be involved in its antifungal activity (Marrez \& Sultan, 2016).

The exposure of $K$. pneumoniae cells to $50 \mathrm{mg} /$ $\mathrm{ml}$ chloroform extract of $M$. aeruginosa resulted in giant cell formation and appearance of elongated filament like structure. The enlargement reduces the relative contact surface. Therefore, bigger cells can tolerate the stress conditions better than normal cells of the same species (Elliott \& Greenwood, 1983). In addition, TEM of the treated $K$. Pneumoniae with the chloroform extract of $M$. aeruginosa MDEG1 revealed successive events of bactericidal effect. These events started with the appearance of loose attachment of bacterial capsules, presence of electron dense granules and electron lucent vacuoles formation in the cytoplasm, weakening and damaging of the boundary cell wall, cell malformation, loose attachment of cell membrane, twisted cell were clearly visible and finally ruptured bacterial cell wall damage with extrusion of cytoplasmic content. Similar successive events that lead to cell death were also observed by Alexander et al., (2006) as an effect of nisin against Bacillus subtilis. Furthermore, the M. aeruginosa MDEG1 chloroform extract possessed the same effect of amoxicillin/clavulanic acid (Augmentin 30 $\mu \mathrm{g}$ ) on K. Pneumoniae (Badawy, 2014).

\section{Conclusion}

The petroleum ether and chloroform extracts of the identified Microcystis aeruginosa MDEG1 
strain exhibited highest antibacterial against K. Pneumoniae and some other Gram negative bacteria. The chloroform extract totally deformed the K. Pneumoniae cells. This might be attributed to the presence of antibacterial compounds such as hexadecanoic acid, hexadecanoic acid methyl ester and dodecanoic acid as revealed by the GC-MS analysis and ${ }^{1} \mathrm{H}$ NMR spectra. More study should be performed in order to purify and identify the exacted antibacterial agent.

\section{References}

Alexander, J.H., Judicael, P., Adam, M.N., Boyan, B.B. (2006) Nisin-induced changes in Bacillus morphology suggests a paradigm of antibiotic action. Biological Sciences Microbiology PNAS, 103, 19896-19909.

Altschul, S.F., Madden, T.L., Schaffer, A.A., Zhang, J., Zhang, Z., Miller, W., Lipman, D..J (1997) Gapped BLAST and PSI-BLAST: A new generation of protein database search programmes. Nucleic Acids Research, 25, 3389-3402.

Ausubel, F.M., Brent, R., Kingston, R.E. (1996) "Current Protocols in Molecular Biology". New York: John Wiley \& Sons.

Badawy, S.A. (2014) Molecular and ultrastructure studies on some antibiotic resistant bacteria. M.Sc. Thesis. Damietta University, Egypt.

Boyer, S.L., Flechtner, V.R., Johansen, J.R. (2001) Is the 16S-23S rRNA internal transcribed spacer region a good tool for user in molecular systematics and population genetics? A case study in cyanobacteria. Molecular Biology and Evolution, 18, 1057-1069.

Chiu, Y., Chen, Y., Wang, T., Yen, H., Lin, T. (2017) A qPCR-based tool to diagnose the presence of harmful cyanobacteria and cyanotoxins in drinking water sources. International Journal of Environmental Research Public Health, 14(5), 547.

Choi, W.H., Jiang, M. (2014) Evaluation of antibacterial activity of hexanedioic acid isolated from Hermetia illucens larvae. Journal of Applied Biomedicine, 12 (3), 179-189.

Desbois, A.P., Mearns-Spragg, A., Smith, V.J. (2009) A fatty acid from the diatom Phaeodactylum tricornutum is antibacterial against diverse bacteria including multiresistant Staphylococcus aureus
(MRSA). Mar Biotechnol. 11, 45-52.

Elliott, T.S., Greenwood, D. (1983) The response of Pseudomonas aeruginosa to azlocillin, ticarcillin and cefsulodin. Journal of General Microbiology, 16, 351-362.

Erdos, G.W. (1986) Localization of carbohydrate containing molecules. In: "Ultrastructure Techniques for Microorganisms", H.C. Aldrich and W.J. Todd (Eds.), pp. 399-420. Plenum Press, New York.

Glauert, A.M. (1975) Fixation methods. in: "Fixation, Dehydration and Embeding of Biological Specimens", pp. 37-110. North Holland Publishing Company $\left(3^{\text {rd }}\right.$ ed. 1980), Amsterdam. The Netherlands.

Grabley, S., Thiericke, R. (1999) Bioactive agents from natural sources: trends in discovery and application. Advances in Biochemical Engineering/ Biotechnology, 64, 101-154.

Hornsey, I.S., Hide, D. (1974) The production of antimicrobial compounds by British marine algae. I. Antibiotic-producing marine algae. British Phycological Journal, 9, 353-361.

Komárek, J., Anagnostidis, K. (1999) Cyanoprokaryota. 1. Chroococcales. In: "Süßwasserflora von Mitteleuropa. Begründet von A. Pascher. Band 19/1", Ettl, H., Gärtner, G., Heynig, H., Mollenhauer, D. (Eds.), pp. 1-548. Heidelberg \& Berlin: Spektrum, Akademischer Verlag.

Kumar, A., Singh, R., Jain, S., Kumar, P. (2011) Synthesis, antimicrobial evaluation, QSAR and in silico admet studies of decanoic acid derivatives. Polish Pharmaceutical Society, 68(2), 191-204.

Lyra, C., Suomalainen, S., Gugger, M., Vezie, C., Sundman, P., Paulin, L., Sivonen, K. (2001) Molecular characterization of planktic cyanobacteria of Anabaena, Aphanizomenon, Microcystis and Planktothrix genera. International Journal of Systematic and Evolutionary Microbiology, 51, 513-526.

Madhumathi, V., Deepa, P., Jeyachandran, S., Manoharan, C., Vijayakumar, S. (2011) Antimicrobial activity of cyanobacteria isolated from freshwater lake. International Journal of Microbiological Research, 2(3), 213-216. 
Marrez, D.A., Sultan, Y.Y. (2016) Antifungal activity of the cyanobacterium Microcystis aeruginosa against mycotoxigenic fungi. Journal of Applied Pharmaceutical Science, 6(11), 191-198.

Mohamed, M.S.M., Abdallah, A.A., Mahran, M.H., Shalaby, A.M. (2018a) Potential alternative treatment of ocular bacterial infections by oil derived from Syzygium aromaticum flower (Clove). Current Eye Research, 43(7), 873-881.

Mohamed, S.H., Mohamed, M.S.M., Khalil, M.S., Azmy, M., Mabrouk, M.I. (2018b) Combination of essential oil and ciprofloxacin to inhibit/ eradicate biofilms in multidrug-resistant Klebsiella pneumoniae. Journal of Applied Microbiology, $\mathbf{1 2 5}, 84-95$

Muruga, B.N., Wagacha, J.M., Kabaru, J.M., Amugune, N., Duboise, S.M. (2014) Effect of physicochemical conditions on growth rates of cyanobacteria species isolated from Lake Magadi, a soda lake in Kenya. WebPub Journal of Scientific Research, 2(5), 53-62.

Nasri, A.B., Bouaïcha, N., Fastner, J. (2004) First report of a microcystin-containing bloom of the cyanobacteria Microcystis spp. in Lake Oubeira, Eastern Algeria. Archives of environmental Contamination and Toxicology, 46, 197-202.

Neilan, B.A., Jacobs, D., Deldot, T., Blackall, L.L., Hawkins, P.R., Cox, P.T., Goodman, A.E. (1997) Ribosomal-RNA sequences and evolutionary relationships among toxic and nontoxic cyanobacteria of the genus Microcystis. International Journal of Systematic Bacteriology, 47, 693-697.

Otsuka, S., Suda, S., Li, R., Watanabe, M., Oyaizu, H., Matsumoto, S., Watanabe, M.M. (1998) 16S rDNA sequences and phylogenetic analyses of Microcystis strains with and without phycoerythrin. FEMS Microbiology Letters, 164, 119-124.

Perumal, P.C., Sophia, D., Raj, C.A., Ragavendran, P., Starlin, T., Gopalakrishnan, V.K. (2012) In vitro antioxidant activities and HPTLC analysis of ethanolic extract of Cayratia trifolia (L.). Asian Pacific Journal of Tropical Disease, 2, S952-S956.

Pradhan, J., Das, S., Das, B.K. (2014) Antibacterial activity of fresh water microalgae: A review. African Journal of Pharmacy and Pharmacology, 8(32), 809-818.
Ramos, D.F., Matthiensen, A., Colvara, W., Souza de Votto, A.P., Trindade, G.S., Almeida da Silva, P.E., Yunes, J.S. (2015) Antimycobacterial and cytotoxicity activity of microcystins. Journal of Venomous Animals and Toxins including Tropical Diseases, 21, 9.

Rinta-Kanto, J.M., Ouellette, A.J.A., Boyer, G.L., Twiss, M.R., Bridgeman, T.B., Wilhelm, S.W. (2005) Quantification of toxic Microcystis spp. Environmental Science Technology, 39, 4198-4205.

Rzymski, P., Poniedzialek, B., Niedzielski, P., Tabacezewski, P., Wiktorowicz, K. (2014) Cadmium and lead toxicity and bioaccumulation in Microcystis aeruginosa. Frontiers of Environmental Science \& Engineering, 8(3), 427-432.

Sasidharan, S., Darah, I., Noordin, M.K.M.J. (2009) Screening antimicrobial activity of various extracts of Gracilaria changii. Pharmaceutical Biology, 47, 72-76.

Stotts, R.R., Namkioshi, M., Haschek, W.M., Rinehart, K.L., Carmichael, W.W., Dahlem, A.M., Beasley, V.R. (1993) Structural modifications imparting reduced toxicity in microcystins from Microcystis spp. Toxicon, 31, 783-789.

Tajbakhsh, S., IIkhani, M., Rustaiyan, A., Larijani, K., Sartavi, K., Tahmasebi, R., Asayesh, G. (2011) Antibacterial effect of the brown alga Cystoseira trinodis. Journal of Medicinal Plants Research, 5 (18), 4654-4657.

Tamura, K., Dudley, J., Nei, M., Kumar, S. (2007) MEGA4: Molecular evolutionary genetics analysis (MEGA) software version 4.0. Molecular Biology and Evolution, 24, 1596-1599.

Tuney, I.B. (2006) Antimicrobial activities of the extracts of marine algae from the coast of Ural (Izmir, Turkey). Turkish Journal of Biology, 30, 171-75.

Via-Ordorika, L., Fastner, J., Kurmayer, R., Hisbergues, M., Dittmann, E., Komárek, J., Erhard, M., Chorus, I. (2004) Distribution of microcystin-producing and non-microcystin-producing Microcystis sp. In European freshwater bodies: Detection of microcystins and microcystin genes in individual colonies. Systematic and Applied Microbiology, 27, 592-602. 
Yadav, S., Sinha, R.P., Tyagi, M.B. (2012) Antimicrobial activity of some cyanobacteria. International Journal of Pharmacy and Pharmaceutical Sciences, 4(3), 631-635.
Zheng,, C.J., Yoo, J.S., Lee, T.G., Cho, H.Y., Kim, Y.H., Kim, W.G. (2005) Fatty acid synthesis is a target for antibacterial activity of unsaturated fatty acids. FEBS Letters, 579, 5157-5162.

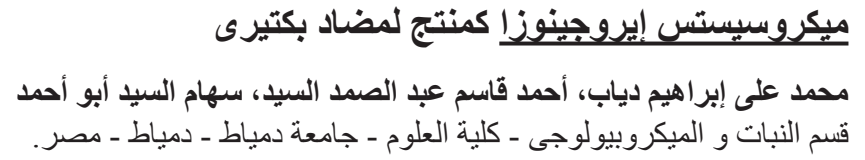

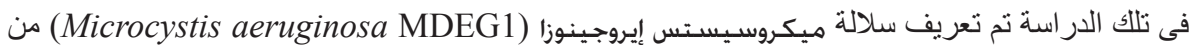

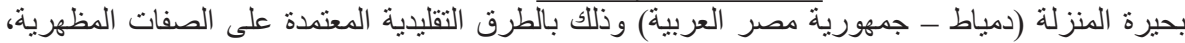

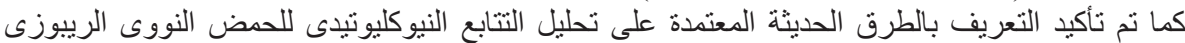

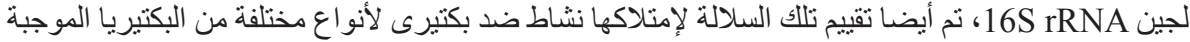

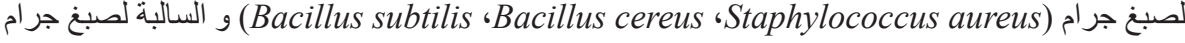
.(Proteus marbili ‘Klebsiella pneumonia ‘Pseudomonas aeruginosa ‘Escherichia coli)

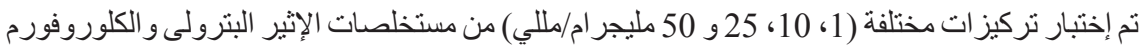

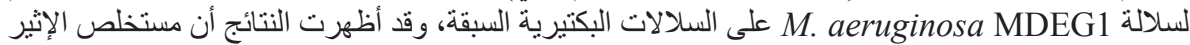

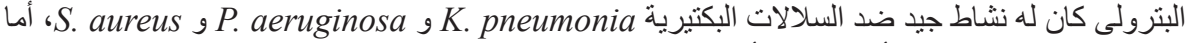

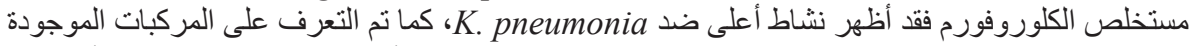

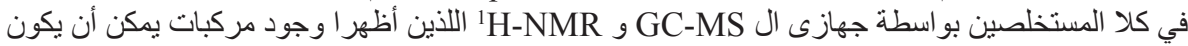

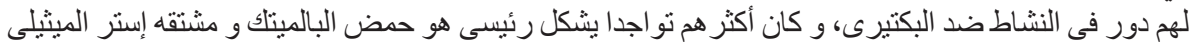

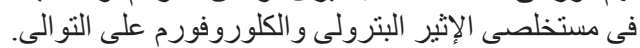

K. pneumonia أظهر الفحص المجهرى بالميكرسكوب الإلكترونى الماسح و القاطع (النافذ) لبكتبريا

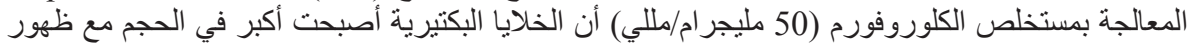

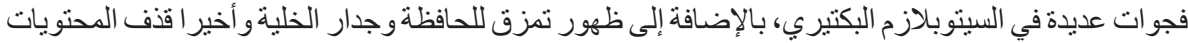

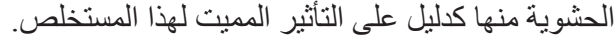

